\title{
Jesus and the six objectives of Daniel 9:24
}

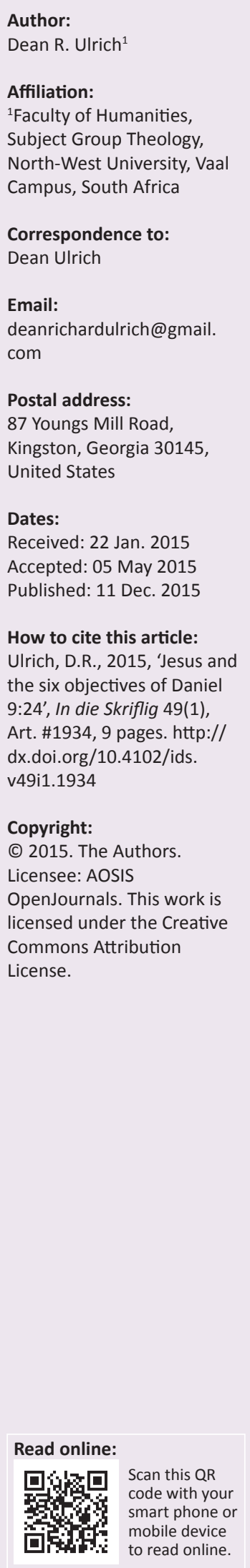

Although Daniel 9:24-27 addresses the Antiochene crisis of the second century BCE, many of Jesus' followers have read this passage with reference to his first and second comings. Following the typological example of the Old Testament and New Testament, this article considers how Jesus is another anointed one that replays the 6th and 2nd century worlds of Daniel 9 and thereby accomplishes the six objectives of Daniel 9:24.

Alhoewel Daniël 9:24-27 die krisis in die tweede eeu v.C. veroorsaak deur Antiogus aanspreek, lees baie van Jesus se volgelinge hierdie gedeelte met verwysing na sy eerste en tweede koms. Hierdie artikel volg die tipologiese verstaan van die Ou Testament en Nuwe Testament en ondersoek tot hoe 'n mate Jesus nóg 'n gesalfde is wat die tweede- en sesde eeuse wêrelde van Daniël 9 hervertolk. Sodoende, voer hierdie artikel aan, vervul dit dus die ses doelwitte van Daniël 9:24.

\section{Introduction}

The New Testament never explicitly cites Daniel 9:24-27 to say that Jesus fulfils the prophecy of the seventy sevens. This author (Ulrich 2014:1062-1083) has previously considered the meaning of this prophecy, including the six objectives of verse 24, for the Antiochene crisis of the second century and early Judaism afterwards. ${ }^{1}$ That crisis consisted of the tyranny of Antiochus IV, the compromises of Hellenistic Jews for economic benefits, and the murder of a legitimate high priest (Onias III). In the structure and details of the seventy sevens or ten jubilee cycles, Jewish readers (e.g. 1 Macc 1:54) first saw a typological relationship between 6th and 2nd century instances of human evil on the one hand and God's preservation of his people's inheritance on the other. By the end of the 1st century CE, Josephus (A.J. 10.11.7 §\$275-276) recognised parallels between the Antiochene and Roman desecrations of the Jerusalem temple and considered them instances of Daniel's abomination of desolation (Dn 9:27; 11:31; 12:11). The history of God's relationship with the Jews featured recapitulation of judgement and blessing. ${ }^{2}$

Not to be overlooked is that Jesus, before Josephus began to write, had already anticipated the Roman destruction of the Jerusalem temple and reinterpreted Daniel's abomination of desolation in view of it (Mt 24:15; Mk 13:14; Lk 21:20). The Gospels, however, never say that Jesus identified himself with the cut off anointed one of Daniel 9:26. He did not claim to be, and the Gospel writers did not portray him as, a second Onias III. Instead, the writer of Hebrews likened Jesus in his priestly role to Melchizedek (Heb 5:10). Even so, many of Jesus' followers have read Daniel 9:24-27 with reference to his first and second comings. ${ }^{3}$ Whether they silently ignore or explicitly deny the interest of Daniel 9 (along with Daniel 8 and 11) in the Antiochene crisis, they identify Jesus as the cut-off anointed one of Daniel 9:26. In death, he is thought to accomplish the six objectives of Daniel 9:24. This article, whilst affirming the Antiochene interest of the seventy sevens, will consider how Jesus is another anointed one that repeats the pattern of the 6th and 2nd century worlds of Daniel 9 and thereby accomplishes the six objectives of Daniel 9:24.
1.See also Ülrich (2015).

2.Collins $(1984: 39,82 ; 1993: 61 ; 1998: 17,51)$ considers the recognition of patterns in history (i.e. typology) a consequence of the vagueness and symbolism of apocalyptic literature, of which Daniel 7-12 is an example. Typology, however, is not restricted to apocalyptic literature. Regardless of genre, Jewish and biblical typology presupposes God's control of history for the accomplishment of his plan of redemption. For more on typology, see Baker (2010:217, 274), Beale (2012:698-699), Goldingay (1977:47-48), Lucas
(2002:254), Meadowcroft and Irwin (2004:201), Osborne (2006:328), and Patte (1975:161-167).

3.Grabbe (1997:596) says, 'Not unexpectedly, most early Christian writers give a Christological interpretation, ending the 70 weeks with the coming of Jesus.' For surveys of the Early Church, see Adler (1996:218-238), Beckwith (1981:539-541), Grabbe (2002:239-243), Hess (2011:320-321), Knowles (1944:136-160), Tanner (2009:185-198), and Van Kooten (2009:297-316). Modern representatives of this approach include Gentry (2010:38), Hess (2011:330), Kline (1974:462-469), Robertson (2004:343), and Young $(1949: 199,201)$. 


\section{How Jesus participates in Daniel's typology}

Unlike the Babylonian exile of the 6th century, the Antiochene crisis of the second century did not involve deportation. Nevertheless, faithful Jews in Judea during the second century could feel alienated from their land because someone else (the Seleucids or compromised Jewish leaders) controlled Judea and them. Jubilee may represent a return to the land from which one had been estranged, but living in the land did not necessarily constitute jubilee. God's people also longed to be independent and faithful in their land. A Hellenised Jewish leader who disregarded God's law (cf. 1 Macc 1:11-15; 2 Macc 4:7-16, 5:6) was no better or preferable than a Seleucid ruler who persecuted those who kept the law (1 Macc 1:41-50; 2 Macc 5:25-26). Under either of them, the alienation persisted, and jubilee (i.e. the restoration of lost inheritance) remained an ideal.

For this reason, a 6th century narrative world in Daniel (and for some readers, a 6th century real world) and a 2nd century real world can be typologically related. In both cases, leaders failed to perform their duties with a concern for God's honor and God's people. Consequently, many of God's people lost sight of their identity and mission and became unrighteous. Jesus encountered a similar situation - irresponsible leaders and wayward people - during his ministry. For this reason, he, after cleansing the temple (Mt 21:12-13; Mk 11:15-16; Lk 19:45-46; cf. 1 Macc 4:41-43), applied the term abomination of desolation to events of his day and beyond (Mt 24:15; Mk 13:14; Lk 21:20). He read Daniel typologically and saw in his day a repetition of the pattern of unbelief and worldliness that the writer of Daniel had applied to Hellenistic Jews during the reign of Antiochus IV (France 2007:911-912; Hagner 1995:700; Vos 1986:95; Wright 1996:351). The Roman invasion and siege of Jerusalem confirmed his insight.

Wright (1996:493) says, 'Jesus' symbolic actions [at the temple] inevitably invoked this entire wider context [of the Maccabean response to Antiochus IV]. Jesus was performing Maccabaean actions, albeit with some radical differences.' He may not have made literal war when he cleansed the temple, but the Antiochene crisis included the murder of a high priest that Jesus eventually replayed. Whatever differences there may be between them, Onias III and Jesus shared unjust suffering and death at the hands of unrighteous sons of Abraham.

Unlike the writer of Hebrews, Matthew may not call Jesus a priest, but Matthew makes a point of explaining the redemptive significance of Jesus' name (Mt 1:21). He then presents Jesus as the one who can forgive sin (Mt 9:2) because he, by dying on a cross, paid the penalty for sin (Mt 20:28). Jesus was the definitive priest because he offered himself as the atoning substitute. In so doing, Jesus was involved in a war that others brought to him and that he took to them. This war that began long before his death involved stripping the spiritual forces of evil of their power to captivate people in rebellion - an outcome that his exorcisms had foreshadowed
(Meyer 1979:155-156; Ridderbos 1962:61-64; Tannehill 1986:88-89). Jesus further conquered the power of sin not by destroying the sinners but by absorbing the punishment for their sins. Because his righteous and unjust suffering became vicariously redemptive, he, indeed, lived up to the meaning that the angel had assigned to his name (Mt 1:21). He saved his people from their sin and reconciled them to God.

Daniel 9:26 forecasts trouble and deprivation for the second anointed one of the seventy sevens, and both certainly found their way to Onias III whose brother, Jason, unlawfully paid Antiochus IV for the office of high priest that Onias III legitimately held (2 Macc 4:7-10; 4 Macc. 4:17). Later, Menelaus unlawfully supplanted Jason and murdered Onias III (2 Macc 4:23-34). Something similar can be said about Jesus. Herod the Great tried to kill Jesus in infancy, and the trouble only continued after that. ${ }^{4}$ The Jewish religious leaders debated Jesus and tried to trap him with his words so that they could kill him. Jesus, however, was not surprised by the opposition. In fact, he seemed to initiate it by his supposedly blasphemous claims and upsetting activities both of which challenged the entrenched power of the religious establishment. Saying that he came to bring a sword instead of peace, he certainly divided families, neighbours, and patriots over his identity (Mt 10:34-35). In some sense, he caused the trouble that eventually put him on the cross. Moreover, Jesus even announced his death. No sooner had Peter called Jesus the anointed one than Jesus predicted his impending suffering and death at the hands of Jewish religious leaders (Mt 16:21). Sure enough, they eventually succeeded in having him executed. The anointed one was cut off, seemingly with nothing. In fact, he never seemed to have much. Whilst alive, the anointed one had no place of sleeping to call his own (Mt 8:20; Lk 9:58). When he died, his friends deserted him out of fear of being guilty by association (Mt 26:56; Mk 14:50), and the Roman soldiers cast lots for his clothes that they had taken away from him (Mt 27:35; Mk 15:24; Lk 23:34; In 19:23). After being cut off, which can entail exclusion and/or extermination (and both happened to Jesus outside Jerusalem), Jesus was buried in someone else's tomb (Mt 27:60). Maybe the worst of all, He had even been disowned by God (Mt 27:46).

At first glance, Jesus did not look like an anointed one who would accomplish the six objectives of Daniel 9:24 and thereby answer Daniel's prayer about mercy for Israel and glory for God (9:17-19). His sinless life surely did not go unnoticed by his contemporaries, but his humble beginnings hardly aroused expectations of royal destiny or priestly intercession. His tendency not to call himself an anointed one further made him an unlikely messianic figure. Moreover, he seemed to come to a tragic end like Onias III and so never realised the hopes that others had for him. Even so, all of this trouble was God's means of inaugurating his kingdom of redemption (cf. Mt 11:12; 20:28), and the Gospels suggest

4. As argued by Atkinson (2004:134-149), precedent for comparing Antiochus IV and Herod the Great exists in the Testament of Moses 8-9. Matthew may not liken Herod the Great exists in the Testament of Moses 8-9. Matthew may not liken
Herod to Antiochus IV, but Herod's foreignness and cruelty certainly fit the Bible's typology of a hostile ruler and could arouse in God's people a longing for a righteous descendant of David. 
that Jesus spent most of his life intentionally looking ahead to his death. By his death, Jesus became greater than Onias III. This observation brings the six objectives of the seventy sevens into view.

\section{How Jesus achieved the six objectives of Daniel 2:24}

Whilst it is true that the New Testament never explicitly cites Daniel 9:24, explicit quotations are not the only way that the writers of the New Testament interacted with the Old Testament. Its categories of thought almost unconsciously shaped their view of the world and especially their view of Jesus. This was certainly true of the book of Daniel (cf. Evans 2002:521; Pennington 2009:286; Wright 1996:598). When Jesus called himself the Son of Man, he did not have to mention Daniel by name as the source of the title. Everybody knew what text was in view. The same could be said about the six objectives of Daniel 9:24. Sin, atonement, righteousness, fulfilment of prophecy, and temple were woven into the fabric of the New Testament world. After Jesus' hermeneutics lesson on Easter Sunday (Lk 24:25-27, 44-47), the New Testament writers instinctively related these topics to the person and work of Jesus.

\section{The first three objectives}

Because the first three objectives concern the problem of sin, they can be grouped together here. It is hardly controversial to say that the New Testament considers the death of Jesus the definitive solution to sin. The New Testament begins with an angelic explanation of Jesus' name in terms of salvation from sin (Mt 1:21), and then the first four books devote considerable attention to narrating Jesus' death. Jesus in Matthew 20:28 and Mark 10:45 describes his impending death as a ransom for many. By calling himself the good shepherd in John 10:11, Jesus says that he willingly lays down his life for the sheep. He later announces in John 12:23, 'The hour has come for the Son of Man to be glorified' in death. When these passages and others are read with recollection of the meaning of Jesus' name, it is evident that Jesus was aware of the atoning purpose of his first coming. The rest of the New Testament agrees with Jesus' self-evaluation (e.g. Ac 13:38; Gl 1:4; Tt 2:14; Heb 9:15, 28; 1 Pt 2:24 3:18; 1 Jn 2:2 4:10; $\operatorname{Rv} 5: 9)$.

Daniel 9:26 may not specifically say that the anointed one's death atoned for sin. Even so, one is not being unreasonable to ask why the death of the second anointed one is mentioned if it has nothing to do with the accomplishing of the six objectives, especially the first three. Moreover, Daniel's prayer implores God to provide a merciful solution to the sins of his people, and the first three objectives of the seventy sevens indicate that God wills to do so. In this atoning context, Gabriel then informs Daniel that an anointed one will be cut off. Meanwhile, Daniel has been reading the book of Jeremiah, which expects an anointed king of exceptional righteousness. This king's reign will be accompanied by the priestly performance of atoning sacrifice (Jr 33:18). Daniel has also handled visions (Nebuchadnezzar's and his) that announce the conquest of human evil by a coming kingdom and king. Furthermore, Daniel and his companions have experienced suffering because of their commitment to the God of Israel, and the God of Israel has used this suffering as a witness to Gentile kings and others. In other words, the Old Testament's pattern of righteous and redemptive suffering occurs in the book of Daniel. So then, linking the death of the anointed one in Daniel 9:26 with the realisation of the six objectives in Daniel 9:24 hardly strain the grammaticalhistorical method of interpretation.

Jesus taught his disciples to read the Old Testament in view of God's program of redemption that reaches its climax in his person and work (Lk 24:26-27, 44-47). The New Testament writers did just this. They may not cite every Old Testament verse and explain how it is fulfilled in Jesus. Instead, they assumed that their readers knew Jesus' hermeneutic, could understand their Christ-centred reading of the Old Testament, and could handle the rest of the Old Testament in a similar way on their own. If associating the anointed one in Daniel 9:26 with the six objectives in Daniel 9:24, especially the first three, makes good hermeneutical sense without Jesus' lesson in Luke 24, that association by generations of Christians after Jesus' Easter teaching is certainly understandable. God uses his anointed ones, especially Jesus the antitype of redemptive suffering, to address the problem of sin.

The New Testament further explains how God answered the two requests of Daniel's prayer: mercy for Israel and glory for God. Firstly, God in Jesus treated his people mercifully by providing atonement at great cost to himself. In so doing, he diverted his wrath onto Jesus who absorbed it along with sin's just penalty. A righteous God propitiated his righteous anger and expiated the consequence of sin without destroying the sinners (Dn 9:16). Secondly, God brought glory to his name through his chosen means of redemption that climaxed at the cross of Jesus. Humans might not pursue glory through redemptive suffering, but Daniel's God is great and awesome (Dn 9:4). He exists in a league by himself and answers prayers in ways that exceed human expectation. Humans can only marvel at 'the depth of the riches of the wisdom and knowledge of God' (Rm 11:33) that regenerates through death.

\section{The fourth objective}

The fourth objective promises everlasting righteousness. Daniel's prayer of confession, which was prompted by his reading of Jeremiah, acknowledges in Daniel 9:7 that God is righteous (צִ צִדָקָ) and that his people, in effect, are unrighteous (Dn 9:18). In fact, they are covered with shame because of their wilful violations of God's commands. Those commands are part of God's covenant that He made with Israel through Moses (Dn 9:4-15). This covenant may have provided the standard of righteous conduct for a people already redeemed by putting their faith in the blood of the Passover lamb; nevertheless, it did not have the power of regeneration within it (Baker 2010:74; Ridderbos 1975:153; Williams 2005:151; Wright 2004:27-29, 52-54, 64-65). The 
blood of animals can neither atone for sin nor change the heart (Heb 10:1-4). Instead, the blood of the Passover lamb typologically anticipated the blood of the Lamb of God that efficaciously takes away the sin of the world (Jn 1:29; 1 Cor 5:7). The power to transform the heart belongs exclusively to Jeremiah's new covenant in Jesus' blood (Lk 22:20; Jn 1:17), and Old Testament saints experienced that power proleptically by believing God's promise regarding the blood of animal sacrifices.

Calvin (1981), as seen in his comments on Jeremiah 31:33, recognised this truth. He said:

the Fathers [Old Testament saints], who were formerly regenerated, obtained this favor through Christ, so that we may say, that it was as it were transferred to them from another source. The power, then, to penetrate into the heart was not inherent in the law, but it was a benefit transferred to the law from the Gospel. (p. 131)

God's grace comes ultimately through Jesus the anointed one. Only the Spirit of Jesus can apply the benefits of Jesus' active and passive obedience to believers and thereby regenerate and transform their hearts. From a historical point of view, Old Testament saints experienced this work of Jesus' Spirit proleptically, and New Testament saints receive it retrospectively.

Transforming grace is the basis for everlasting righteousness. Because Jesus kept the law of God without infraction, He is the righteous one who can satisfy the justice of God by paying sin's penalty. The resurrection proves God's acceptance of Jesus' work. Not only does the resurrection vindicate Jesus as the Righteous One (Ac 2:24, 33; Rm 1:4; 1 Tm 3:16) but it also makes him able to share his righteousness with those who believe in him (Beale 2011:253-254, 262-263, 473-477, 493-498, 575-588; Gaffin 1987:89-92, 114-117, 120-129; Vos 1980:107, 109-114; Vos 1986:151). The Spirit of Jesus graciously applies the righteousness of Jesus to believers so that they become positionally and progressively conformed to his likeness through justification, sanctification, and glorification. As they reflect his righteousness in character and conduct, righteousness spreads throughout their areas of influence. Stated differently, the kingdom of God advances on earth as God's people exhibit the righteousness of Jesus that the Spirit of Jesus imputes to and grows in them.

The Mosaic covenant had to do with the sanctification and mission of an already redeemed people. It told them how to live righteously in response to God's preliminary and anticipatory provision of redemption in the Exodus. As seen, for example in Paul's association of the law with love (Rm 13:8-10), the Mosaic instruction continues to have the same role in the lives of New Testament saints. It defines how a royal priesthood carries out its mission to model a redeemed and righteous alternative to the disobedience of God's revealed will that characterises this present evil age. The observance of dietary, sacrificial, and other laws may require adjustment because of the movement of redemptive history, but the abiding truths behind these laws remain in effect.
Jesus who kept the law in order to perform Israel's priestly mission, enables his people to keep it for a similarly priestly (i.e., evangelistic) purpose (cf. 1 Pt 2:9-3:17).

If Daniel's reading of Jeremiah's recalls the new covenant that makes righteousness possible through the internalisation of God's law, Jeremiah also expected a future king named Yahweh Is Our Righteousness (Jr 23:5-6; 33:15-16). This descendant of David would act righteously and establish righteousness. No such king appeared after Jeremiah's ministry until Jesus, and certainly Jehoiakim, the only Davidic descendant mentioned in Daniel, failed to exemplify righteousness (cf. Jr 22:13-19). By identifying Jesus the anointed one as the son of David, the first verse of the New Testament signals that King Yahweh Is Our Righteousness has arrived. Through him, God fully answered Daniel's prayer by turning away his anger in accordance with his righteousness (Dn 9:16). Jesus the righteous king saved his people from divine judgement by living sinlessly, paying sin's penalty, and breaking sin's power. He defeated their enemies - internal and external, earthly and spiritual, human and demonic, seen and unseen. Jesus also claimed to be Daniel's Son of man who is said to receive dominion, majesty, and a kingdom (Dn 7:13-14). As such, Jesus inherited and realised the royal commission given to Adam, the first human (Gn 1:28), and later to the Davidic kings (Ps 72). He rules righteously over the creation for God's glory, the benefit of God's people, and the good of God's other creatures.

One other point should be made in connection with the fourth objective. Daniel 2:37 says that the God of heaven gives dominion to Nebuchadnezzar, but not forever. Three other kingdoms follow his. Moreover, verse 38 limits Nebuchadnezzar's rule to humans, beasts, and birds creatures that dwell on earth. Verse 39 even explicitly says that the third kingdom will rule over all the earth. None of the four kingdoms, however, rules over heaven. So then, Daniel 2 contrasts the human kingdoms of earth and God's kingdom of heaven (Pennington 2009:272). That focus is especially seen in Matthew's preference for the phrase kingdom of heaven instead of kingdom of God. ${ }^{6}$ Mark 1:15 reports that Jesus began his ministry during the Roman Empire by proclaiming, 'The time has come; the kingdom of God is at hand'. Curiously, Matthew 4:17 (a parallel verse) and other verses in Matthew refer to the kingdom of God as the kingdom of heaven. According to Pennington (2009:289-290, 320-321), the writer of Matthew did not use a 'reverential circumlocution' to avoid direct reference to God (as was done in the literature of the Second Temple Judaism) but, instead, applied to Jesus the contrast in Daniel 2 between the human kingdoms of earth and the divine kingdom of heaven. This contrast involves not only ontology (Jesus in contrast to the kings in Daniel 2 is more than human) but also ethics (Jesus' reign is characterised by righteousness). Pennington (2009:209)

5.On Jesus as the new Israel that recapitulates the mission of old Israel and performs it, see Beale (2011:406, 416-418), Kennedy $(2008: 23-24,154-155,219)$, McCartney and Enns (2001:103), Meyer (1979:240-241), and Wright (1996:597, 608-609).

6.The phrase kingdom of God is not completely absent in Matthew. It occurs in Matthew $12: 28 ; 19: 24 ; 21: 31 ; 21: 43$, and perhaps $6: 33$. 
says, 'He [Matthew] is crafting a sharp distinction between two realms: one represented by the earthly world and its unrighteous inhabitants and the other by God', who, of course, embodies righteousness and sends his eternal Son in human dress. The Son in his deity shares the attribute of righteousness and then reflects it as the image of God in his humanity. Each person, then, must make a decision about serving one of two possible masters (Mt 6:24), and the outcomes in terms of conduct and consequences could not be starker.

At this point, it is hard not to think that Matthew's contrast between heaven and earth constitutes his way of distinguishing between the two ages that characterise New Testament eschatology as a whole (e.g. Gl 1:4). ${ }^{7}$ Although Pennington (2009:334) prefers to speak of two realms - an earthly realm (characterised by disobedience to God's commands) and a heavenly realm (characterised by willing submission to King Jesus) that remain in tension until the eschaton - he recognises that Matthew is aware of moral duality (good versus evil) and eschatological duality (this age and the age to come). Whereas human kingdoms represent this present evil age that lives without reference to God and so suffers the deleterious consequences of unrighteous thought and conduct, the kingdom of heaven has to do with the age to come that irrupts into this present evil age through the person and work of God's incarnate Son. These two incompatible ages run concurrently between the first and second comings of Jesus until God's kingdom and king overthrow the evil regimes of human history and cause righteousness to prevail in human hearts and upon the earththe fourth objective of Daniel 9:24.

\section{The fifth objective}

The seventy sevens disclose what God will do in the future in order to answer Daniel's twofold prayer for mercy for Israel and glory for God. Stated differently, the seventy sevens announce God's promises and state his intention to fulfil those promises. Sealing prophetic vision, which is the fifth objective, has to do with promise and fulfilment. Promise and fulfilment assume God's continued activity in history to work out his plan of redemption. Gabriel assures Daniel that God's purpose for his people did not end in exile. God still has more in store for them, and he will finish what he has announced. The seventy sevens, of course, do not constitute the first promise of God in the Old Testament. By the time that Gabriel appeared to Daniel, Yahweh already had an established track record of announcing his intention and then performing his word. Still, the Old Testament ends with an incomplete story and some promises unfulfilled.

Not surprisingly, then, the New Testament opens with Matthew's announcements of fulfilment. Whilst some of his Old Testament citations were not predictions in their $7.0 n$ the two ages in New Testament eschatology, see Hoekema (1979:13-75),
Ladd (1974:68-69, 302-303, 329, 364-365, 550-552, 573-577, 591, 595-597), Ridderbos (1957:63-70; 1975:44-53, 91-93), and Vos (1986:1-41).
Old Testament context, Matthew considered the whole Old Testament the beginning of God's story that foreshadows the climax and consummation in the person and work of Jesus (cf. France 2007:11; Wright 1992:63). Matthew was not alone in reading the beginning of the story in view of the end, for other disciples heard Jesus' hermeneutics lesson on Easter Sunday (Lk 24:25-27, 44-47). Jesus changed the way that they read the Old Testament. They realised that the Spirit who inspired the prophets was talking about something or someone that the prophets could not fully comprehend at the time (1 Pt 1:10-12). The authors of the New Testament drew the strands of Old Testament theology together so that they converged on Jesus, as God had intended. Jesus fit the pattern that the Old Testament introduced and developed. He was the climax and fulfilment of God's eternal plan.

Daniel 9:24 is not the only reference to sealing in Daniel. Daniel is also told to seal a vision (Dn 8:26) and a book (Dn 12:4) until the time of the end. The contents of both are a mystery that only Jesus, according to the New Testament, can disclose. As both the message and the messenger of God, Jesus came in the fullness of time to inaugurate God's kingdom of redemption. He alone, by virtue of his death for sin, has the right to open the seals on the revelation of God's salvation of his world and people ( $\operatorname{Rv} 5: 9-10)$. Moreover, Jesus alone, by virtue of his resurrection that attests to the satisfaction of divine justice, guarantees the announcement of God's victory over evil and God's vindication of those for whom Jesus died.

\section{The sixth objective}

Gabriel informed Daniel that the seventy sevens would anoint the most holy one (either a place or a person). Given Daniel's plea for the restoration of God's desolate sanctuary (Dn 9:17), the sixth objective would seem to have a building and not a person in view. The Old Testament and intertestamental literature may never record the return of God's glory to the second temple, but the Gospel of John does. John 1:14 says that the Word, earlier identified as God, took a human nature and lived on earth amongst us people.

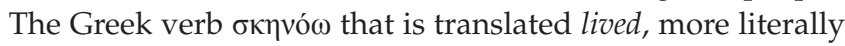

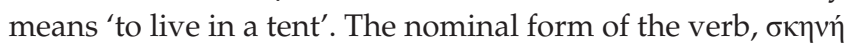
[tent], is regularly used in the Septuagint for the Hebrew [tabernacle]. John says that we have seen in Jesus the glory

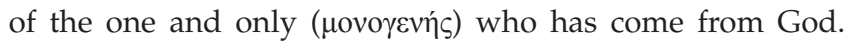
Moreover, John 2 records Jesus' cleansing of the temple. When confronted by the Jews about his authority, Jesus said that he would destroy the temple and raise it in three days (Jn 2:19). John adds that Jesus had the temple of his body in mind, not Herod's temple. The first two chapters of John, then, associate Jesus with the tabernacle and temple. The glory of God returned to take up residence not in the קדָדש קָדָדָשים [Tost

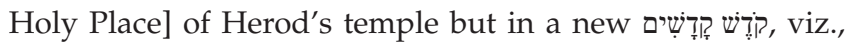
Jesus' body (cf. Meadowcroft 2001:448; Spatafora 1997:294). As Immanuel, which means God with us (Mt 1:23), Jesus is Daniel's anointed קָדָשׁ קָדָשִׁים and Ezekiel's new temple (cf. Gruenthaner 1939:47-48). 
The parallels between Ezekiel 40-48 and Jesus continue in John. In John 4, Jesus meets a Samaritan woman at a well and strikes up a conversation with her by asking for a drink. Astonished that a Jewish man would pay attention to her, she asks why he is talking to her. Jesus responds by saying that she, if she knew who he was, would ask him for a drink and would receive living water. Confused and even offended, she asks how Jesus can give her water. Jesus says that his water relieves thirst forever and produces a spring of eternal life within those who drink it. If John has already identified Jesus as the new temple, this conversation with the Samaritan woman further establishes him as the source of the river of God's redeeming grace that flows from Ezekiel's new temple (cf. Spatafora 1997:114). Jesus will do no less than transform creation, not by literally desalinating the Dead Sea but by reversing the curse and restoring paradise. Moreover, the river of God's grace that runs from Jesus into the woman makes her a temple of the Holy Spirit. The glory of God now dwells in her, and she, in Christ, becomes Ezekiel's new

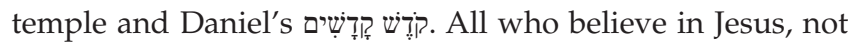
just the Samaritan woman, drink of his river and become temples of the Spirit of Jesus (Jn 7:37-39; 1 Cor 3:16; Eph 2:22; 1 Pt 2:5).

Revelation 21:22 goes so far as to say that no temple is in the New Jerusalem. This observation might initially seem to contradict Daniel and Ezekiel, but not really. Ezekiel 48 expands the Most Holy Place to include the new city (cf. Briggs 1999:104-108, 221-223; Mathewson 2003:111-115, 223-224). John recognised this truth and combined it with his belief that the glory of God took up residence in Jesus. Jesus and those who believe in him become the most holy one. For this reason, Revelation 21:18 reports that the New Jerusalem is made of pure gold. Gold in the city recalls the gold interior of Solomon's temple (1 Ki 6:21-22; 2 Chr 3:4-9). The whole city becomes a קָדָש קָדִָּשים (cf. Beale 2011:553554, 640; Mathewson 2003:153-154). No temple is necessary because God through Jesus resides without impediment in the midst of his people (cf. Spatafora 1997:237, 239). They are the temple that has become a people in an unbounded place (i.e. everywhere) rather than a circumscribed place amongst a multitude of people (Gundry 1987:254-264).

The writer of Daniel may not have been able to make all of these connections, and one wonders how much the writer of 1 Enoch 24-36 understood of his geographical discussion of radiating righteousness. In fact, 1 Peter 1:10-12 says that the prophets of the Old Testament struggled to understand what they were saying, but under the direction of the Holy Spirit, wrote better than they knew. With the benefit of Jesus' teaching in Luke 24, the apostles could say that what the prophets had announced was being realised in Jesus. Jesus is the new temple, the Holy of Holies, Immanuel, and the glory of God. He puts an end to sin by atoning for it. He establishes righteousness in his people and throughout the world by imputing his righteousness to his people and satisfying the justice of God by his vicarious death for the sins of his people. Moreover, his Spirit conforms his people to his likeness. He restores communion between God and his creation. In sum, Jesus can be viewed as the answer to Daniel's prayer for the mercy and glory of God. He accomplishes the six objectives of the seventy sevens and thereby ushers in the Jubilee of Jubilees.

\section{The six objectives and New Testament eschatology}

Gabriel informed Daniel that the objectives of the six infinitives would take seventy sevens to reach realisation. Whether seventy sevens are understood more literally as 490 years or more symbolically as ten jubilee cycles, no interpretive approach can escape the reality that arguably five of the six objectives have yet to achieve complete fulfilment. The one exception is the third objective. Jesus has already made the final and definitive sacrifice for $\sin$. His atoning death paid the penalty for the sins of his people, regardless of their place in history. Jesus died once for all (Heb 9:12, 24-28). That the Holy Spirit applies the benefits of Jesus' work down through history to individual believers so as to regenerate and sanctify them does not detract from Jesus' affirmation on the cross, 'It is finished'. The on-going ministry of the Holy Spirit, both before the cross and after, is made possible by the finished work of Jesus.

As for the other objectives in Daniel 9:24, they have an 'already-not yet' quality to them. Regarding the first two objectives, neither the Maccabean crisis nor the first coming of Jesus put an end to sin (cf. Kaiser 2011:105-106; Robertson 2004:343; Wright 1996:659). People, whether Christian or not, still sin by breaking the Ten Commandments. Even Paul, who told the Romans that sin would no longer master them (Rm 6:14), admitted that he did not always do the good that he wanted or avoid the evil that he loathed (Rm 7:19). Moreover, Paul had to reprimand Peter for reverting to his former Jewish exclusivism and shunning Gentile Christians out of fear of a small group of Judaisers (Gl 2:11-14). The apostles did not achieve perfection in this life, and neither does anyone else. Since Daniel received a visit from Gabriel, the human race in general and God's people in particular persist in failing to love one another in thought, word, and deed. Children still disobey and dishonour their parents. Couples still cheat on one another and steal from someone else what is not theirs by right of marriage. People still misrepresent the truth to protect themselves or to gain some advantage. God's world has not yet been fully reconciled to his eternal plan, and evidence abounds that the world is not yet the way it is supposed to be. It still labours under the effects of the fall and the curse in Genesis 3.

The presence of sin in the world, of course, means that the fourth objective (everlasting righteousness) awaits full realisation. As Jeremiah's righteous king, the sinless Jesus may impute his righteousness to those who trust in him for justification, but every Christian's experience lags behind his or her position. Paul remarkably claims that Christians are now seated with Christ in the heavenly realms (Eph 2:6), but 
the same letter tells its recipients to eliminate all bitterness, rage, anger, brawling, and slander (Eph 4:31). The imperative would not be necessary if none of this unrighteous behaviour existed amongst the Ephesian Christians.

As for the fifth and sixth objectives, they, too, await complete fulfilment. Not all prophecy has yet come to pass - the fifth objective. For example Isaiah's expectation of a new heaven and earth, purged of the effects of the curse, is not yet a reality, nor are the prophetic threats against the enemies of God and his people. Jesus, for example stopped short of saying that the day of vengeance in Isaiah 61:2 found fulfilment today in the Nazareth synagogue (Luke 4:19). Instead, he mentioned a future time when he would come in glory to judge the sheep and the goats (Mt 25:31-46). Referring to the same event, Paul said that Jesus would inflict vengeance on those who neither know God nor obey the gospel (2 Th 1:8). If anointing

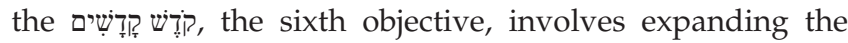
perimeter of the Most Holy Place so that it fills the earth, then God's creation has yet to become a sanctuary of pure worship. From a biblical point of view, much false and abominable worship still occurs in God's world. Moreover, those who believe in Jesus may be temples of the Holy Spirit, but the Corinthian Christians to whom Paul first applied the description kept him busy with pastoral care. Similarly, church history up to the present offers a steady stream of unchristian conduct.

So then, what the prophets in general expected after the exile and what Gabriel in particular announced for the seventy sevens has progressively but partially materialised in history. Some difference, though, exists between the future outlook of the prophets (including Daniel) on the one hand, and the New Testament on the other (cf. Beale 2011:161-162; Hoekema 1979:12-22). The prophets looked ahead to one coming of God that would set matters right in a fallen world. God would judge the wicked and vindicate the righteous. He would save his people from their sins and restore his creation that now labours under a curse. For the writer of Daniel, the future began in 539 все when the seventy sevens started counting down. At the end of these in the 2nd century, God had not come, and the six objectives of the seventy sevens had not reached fruition. The New Testament then reports the first coming of God in Jesus. It looks not only back at what God began to do at the first coming of Jesus but also forward to what he will finish at the second coming of Jesus. It recognises that not everything for which the Old Testament hoped became reality in the first century CE. Whereas the Old Testament expected one coming of God, the New Testament informs its readers that there will be two. The period in between the two comings provides the stage on which God continues to fulfil his promises. The second coming of Jesus will mark the full realisation of the six objectives of the seventy sevens.

Recognising the difference between Old Testament eschatology and New Testament eschatology helps to explain how interpreters who read Daniel 9:24-27 with reference to the Antiochene crisis (the standard scholarly view), the first coming of Jesus (the standard reformed and perhaps evangelical view), or a seven-year period of tribulation for the modern state of Israel before the second coming of Jesus (the dispensational view) have something to contribute to the discussion. The seventy sevens, which run from the end of the Babylonian exile to the end of Antiochus IV, can speak meaningfully to any moment in history because they contribute to a pattern that appears throughout the Christian Bible. That pattern has to do with God's progressive and organic accomplishment of the six objectives of Daniel 9:24 throughout the events of redemptive history. Stated differently, jubilee comes in stages.

For this reason, both Old Testament eschatology and New Testament eschatology feature tension between what God has already done in fulfilment of his promises and what still awaits realisation. The so-called tension between the already and the not yet does not characterise New Testament eschatology alone. Postexilic literature is especially aware of the poignancy of an incomplete, but not wholly future, restoration (cf. Bright 1975:206-208). God started to do Isaiah's new thing (Is 43:19) in 539 все. Daniel's seventy sevens also began counting down at that same time. But God did not finish Isaiah's new thing or the six objectives of Daniel's seventy sevens by the completion of the second temple in 516 все, the erection of Nehemiah's wall in 445 все, the Maccabean victory in $164 \mathrm{BCE}$, the death of Jesus about $30 \mathrm{CE}$, or the destruction of Herod's temple in $70 \mathrm{CE}$. Two millennia later, he is still ushering in Isaiah's new thing and accomplishing the six objectives of Daniel's seventy sevens (though the sevens are no longer counting down). From 539 BCE to the present, God's people have been united by their experience of tension between what God has promised and what God has so far done. If the prophecy of seventy sevens is read with this tension in mind, then one can learn from the major approaches and yet recognise that none has adequately explained the tension.

Meanwhile, the New Testament emphasises the tension by referring to followers of Jesus as aliens and strangers in this present evil age (1 Pt 2:11). Like the Israelites in Egypt, in Babylon, and under the rule of Antiochus IV and Hellenised Jews, Christians await the Jubilee of Jubilees. They may have experienced a foretaste of jubilee by means of what Jesus accomplished at his first coming, but the fullness of jubilee (i.e. the complete enjoyment of the six objectives of Daniel 9:24) remains a future event for which Christians wait with longing as well as joy (1 $\mathrm{Pt}$ 1:6-9). Whilst one could read Daniel 9:24-27 with cynicism and say that jubilee never came in the second century and has not come since, Antiochus IV did die and so also did the Hasmonean rulers. ${ }^{8}$ Moreover, none of them came back to life. By contrast, Jesus demonstrated righteousness in life and then willingly laid down his righteous life as an atoning sacrifice for sin. As proof of God's satisfaction with 8.Cf. Wallace (1984:165) who considers the Antiochene reading of Daniel 9:24-27 sensational with Merrill Willis (2010:179) who uses the word penultimate for apocalyptic visions. 
his redemptive work, Jesus rose from the dead, ascended into heaven, and promised to return in majesty. Not to be missed is the exceptional integrity of Jesus. Jesus, according to the New Testament, is an anointed one who exercises the offices of king and priest by conquering evil through personal sacrifice. Antiochus IV and the Hasmonean rulers knew nothing of such unselfish ministry for others. Neither have most other political leaders.

\section{Summary}

This article has focused on what Daniel 9:24-27 means in the New Testament period and beyond. It is true that the New Testament never explicitly cites Daniel 9:24. Still, Jesus is another anointed one and the final Anointed One. The New Testament considers the death of Jesus the definitive solution to $\sin$ (the first three objectives). Jesus makes believers in him righteous so that they can act righteously (the fourth objective). He fulfils prophecy (the fifth objective) by bringing redemptive history to its goal, which is his exaltation through the salvation of his people. Moreover, he, as Immanuel (God with us), is the Holy of Holies that sanctifies the whole world (the sixth objective). By finishing the accomplishment of the six objectives of the seventy sevens, Jesus brings the fullness of jubilee.

\section{Acknowledgements Competing interests}

The author declares that he has no financial or personal relationship(s) that may have inappropriately influenced him in writing this article.

\section{References}

Adler, W., 1996, 'The apocalyptic survey of history adapted by Christians: Daniel's prophecy of 70 weeks', in J.C. Vanderkam \& W. Adler (eds.), The Jewish apocalyptic heritage in early Christianity, pp. 201-238, Van Gorcum, Assen. (Compendia Rerum ludaicarum ad Novum Testamentum 3.4).

Atkinson, K., 2004, 'Herod the Great as Antiochus Redivivus: Reading the Testament of Moses as an anti-Herodian composition', in C.A. Evans (ed.), Of Scribes and sages: Early Jewish interpretation and transmission of Scripture, vol. 1 pp. 134-149, T \& T Clark International, London. (Studies in Scripture in Early Judaism and Christianity 9; Library of Second Temple Studies 50).

Baker, D.L., 2010, Two Testaments, one Bible: The theological relationship between the Old and New Testaments, 3rd edn., InterVarsity, Downers Grove.

Beale, G.K., 2011, A New Testament biblical theology: The unfolding of the Old Testament in the New, Baker, Grand Rapids.

Beale, G.K., 2012, 'The use of Hosea 11:1 in Matthew 2:15: One more time', Journal of the Evangelical Theological Society 55(4), 697-715.

Beckwith, R.T., 1981, 'Daniel 9 and the date of Messiah's coming in Essene, Hellenistic Pharisaic, Zealot and Early Christian computation', Revue de Qumran 10(4), 521-542.

Briggs, R.A., 1999, Jewish temple imagery in the book of Revelation, Peter Lang, New York. (Studies in Biblical Literature 10).

Bright, J., 1975, The authority of the Old Testament, Baker, Grand Rapids. (Twin Brooks Series).

Calvin, J., 1981, Commentaries on the book of the prophet Jeremiah and the Lamentations, vol. 4, Baker, Grand Rapids.

Collins, J.J., 1984, Daniel with an introduction to apocalyptic literature, Eerdmans, Grand Rapids. (The Forms of the Old Testament Literature 20).

Collins, J.J., 1993, Daniel: A commentary on the book of Daniel, Fortress, Minneapolis. (Hermeneia).

Collins, J.J., 1998, The apocalyptic imagination: An introduction to Jewish apocalyptic literature, 2nd edn., Eerdmans, Grand Rapids. (Biblical Resource Series).

Evans, C.A., 2002, 'Daniel in the New Testament: Visions of God's kingdom', in J.J. Collins \& P.W. Flint (eds.), The book of Daniel: Composition and reception, vol. 2, pp. 490-527, Brill, Boston.
France, R.T., 2007, The Gospel of Matthew, Eerdmans, Grand Rapids. (New International Commentary on the New Testament).

Gaffin, R.B., Jr., 1987, Resurrection and redemption: A study in Paul's theology, 2nd ed., P \& R Publishing, Phillipsburg. (Biblical and Theological Studies).

Gentry, P.J., 2010, 'Daniel's seventy weeks and the new exodus', Southern Baptist Journal of Theology 14(1), 26-44.

Goldingay, J.E., 1977, 'The book of Daniel: Three issues', Themelios 2(2), 45-49.

Grabbe, L.L., 1997, 'The seventy weeks prophecy (Daniel 9:24-27) in early Jewish interpretation', in C.A. Evans \& S. Talmon (eds.), The quest for context and meaning: Studies in biblical intertextuality in honor of James A. Sanders, and meaning: Studies in biblical intertextuality in honor of
pp. 595-611, Brill, Leiden. (Biblical Interpretation Series 28).

Grabbe, L.L., 2002, 'A Dan(iel) for all seasons: For whom was Daniel important?' in J.J. Collins \& P.W. Flint (eds.), The book of Daniel: Composition and reception, vol. 1, pp. 229-246, Brill, Boston.

Gruenthaner, M.J., 1939, 'The seventy weeks', Catholic Biblical Quarterly 1(1), 44-54.

Gundry, R.H., 1987, 'The new Jerusalem: People as place, not place for people', Novum Testamentum 29(3), 254-264. http://dx.doi.org/10.2307/1560758

Hagner, D.A., 1995, Matthew 14-28, Word, Dallas. (Word Biblical Commentary 33в).

Hess, R.S., 2011, 'The seventy sevens of Daniel 9: A timetable for the future?', Bulletin for Biblical Research 21(3), 315-330.

Hoekema, A.A., 1979, The Bible and the future, Eerdmans, Grand Rapids.

Kaiser, W.C., 2011, Preaching and teaching the last things: Old Testament eschatology for the life of the church, Baker, Grand Rapids.

Kennedy, J., 2008, The recapitulation of Israel: Use of Israel's history in Matthew 1:1-4:11, Mohr Siebeck, Tübingen. (Wissenschaftliche Untersuchungen zum Neuen Testament 2/257)

Kline, M.G., 1974, 'The covenant of the seventieth week', in J.H. Skilton (ed.), The law and the prophets: Old Testament studies in honor of Oswald T. Allis, pp. 452-469, Presbyterian \& Reformed Printers, Nutley.

Knowles, L.E., 1944, 'The interpretation of the seventy weeks of Daniel in the early Fathers', Westminster Theological Journal 7(2), 136-160.

Ladd, G.E., 1974, A theology of the New Testament, Eerdmans, Grand Rapids.

Lucas, E.C., 2002, Daniel, InterVarsity, Downers Grove. (Apollos Old Testament Commentary 20).

Mathewson, D., 2003, A new heaven and a new earth: The meaning and function of the Old Testament in Revelation 21.1-22.5, Sheffield Academic Press, London. (Journal for the Study of the New Testament Supplement Series 238).

McCartney, D. \& Enns, P., 2001, 'Matthew and Hosea: A response to John Sailhamer', Westminster Theological Journal 63(1), 97-105.

Meadowcroft, T., 2001, 'Exploring the dismal swamp: The identity of the anointed one in Daniel 9:24-27', Journal of Biblical Literature 120(3), 429-449. http://dx.doi. org/10.2307/3267901

Meadowcroft, T. \& Irwin, N., 2004, The book of Daniel, Asia Theological Association, Singapore. (Asia Bible Commentary Series).

Merrill Willis, A.C., 2010, Dissonance and the drama of divine sovereignty in the book of Daniel, T \& T Clark International, New York. (Library of Hebrew Bible; Old Testament Studies 520).

Meyer, B.F., 1979, The aims of Jesus, SCM, London.

Osborne, G.R., 2006, The hermeneutical spiral: A comprehensive introduction to biblical interpretation, rev. edn., InterVarsity, Downers Grove.

Patte, D., 1975, Early Jewish hermeneutic in Palestine, Scholars Press, Missoula. (SBL Dissertation Series 22).

Pennington, J.T., 2009, Heaven and earth in the Gospel of Matthew, Baker, Grand Rapids.

Ridderbos, H., 1957, Paul and Jesus: Origin and general character of Paul's preaching of Christ, trans. D.H. Freeman, Presbyterian \& Reformed Publishers, Nutley.

Ridderbos, H., 1962, The coming of the kingdom, trans. H. de Jongste, Presbyterian \& Reformed Publishers, Philadelphia.

Ridderbos, H., 1975, Paul: An outline of his theology, trans. J.R. de Witt, Eerdmans, Grand Rapids.

Robertson, O.P., 2004, The Christ of the prophets, P \& R Publishing, Phillipsburg.

Spatafora, A., 1997, From the temple of God to God as the temple: A biblical theological study of the temple in the book of Revelation, Gregorian University Press, Rome. (Tesi Gregoriana Serie Teologia 27).

Tannehill, R.C., 1986, The Gospel according to Luke, vol. 1 of The narrative unity of Luke-Acts: A literary interpretation, Fortress, Philadelphia.

Tanner, J.P., 2009, 'Is Daniel's seventy weeks prophecy messianic? Part 1', Bibliotheca Sacra 166(662), 181-200.

Ulrich, D.R., 2014, 'How early Judaism read Daniel 9:24-27', Old Testament Essays 27(3), 1062-1083.

Ulrich, D.R., 2015, The Antiochene crisis and jubilee theology in Daniel seventy sevens, Brill, Leiden. (Oudtestamentische Studiën).

Van Kooten, G.H., 2009, 'The desecration of "The Most Holy Temple of all the world" in the "Holy Land": Early Jewish and Early Christian recollections of Antiochus' "Abomination of desolation"', in J. van Ruiten \& J.C. de Vos (eds.), The land of "Asrael in Bible, history, and theology: Studies in honour of Ed Noort, pp. 291-316, Brill, Leiden. (Supplements to Vetus Testamentum 124). 
Vos, G., 1980, 'The eschatological aspect of the Pauline conception of the Spirit', in R.B. Gaffin (ed.), Redemptive history and biblical interpretation: The shorter writings of Geerhardus Vos, pp. 91-125, P \& R Publishing, Phillipsburg.

Vos, G., 1986, The Pauline eschatology, P \& R Publishing, Phillipsburg.

Wallace, R.S., 1984, The message of Daniel, InterVarsity, Downers Grove.

Williams, M.D., 2005, Far as the curse is found: The covenant story of redemption, P \& R Publishing, Phillipsburg.
Wright, C.J.H., 1992, Knowing Jesus through the Old Testament, InterVarsity, Downers Grove.

Wright, C.J.H., 2004, Old Testament ethics for the people of God, InterVarsity, Downers Grove.

Wright, N.T., 1996, Jesus and the victory of God, Fortress, Minneapolis. (Christian Origins and the Question of God 2)

Young, E.J., 1949, The prophecy of Daniel: A commentary, Eerdmans, Grand Rapids. 